\title{
New distribution record of Elysia leucolegnote (Jensen, 1990) (Sacoglossa Plakobranchidae) in mangrove ecosystem of Biak Numfor, Papua - Indonesia
}

\author{
Mardiansyah ${ }^{1,2^{*}}$ \& Yusli Wardiatno $0^{3,4,5}$ \\ ${ }^{1}$ Department of Biology, Faculty of Science and Technology, Syarif Hidayatullah State Islamic University, Jl. Ir. H. Djuanda No. \\ 95, Ciputat, Tangerang Selatan 15412, Banten, Indonesia. \\ ${ }^{2}$ Laboratory of Ecology, Center for Integrated Laboratory (PLT), Syarif Hidayatullah State Islamic University, Jl. Ir. H. Djuanda \\ No. 95, Ciputat, Tangerang Selatan 15412, Banten, Indonesia. \\ ${ }^{3}$ Department of Aquatic Resources Management, Faculty of Fisheries and Marine Sciences, Bogor Agricultural University, Jl. Raya \\ Dramaga, Kampus IPB Darmaga, Bogor 16680, West Java, Indonesia \\ ${ }^{4}$ Environmental Research Center, Bogor Agricultural University, Jl. Raya Dramaga, Kampus IPB Darmaga, Bogor 16680, West \\ Java, Indonesia. \\ ${ }^{5}$ Center for Coastal and Marine Resources Studies, Bogor Agricultural University, Jl. Raya Pajajaran, Kampus IPB Baranangsiang, \\ Bogor 16143, West Java, Indonesia. \\ "Corresponding author, e-mail: ymar.assuyuti@uinjkt.ac.id
}

ABSTRACT Elysia leucolegnote (Jensen, 1990) (Sacoglossa Plakobranchidae) was firstly found in Hong Kong and described in 1989. Furthermore, in the past decade, the mangrove leaf-slug, E. leucolegnote, has been found outside Hong Kong, for example in Thailand, India, and Australia, but it is here reported for the first time in Indonesia. Details on the distribution, habitat and external morphology of E. leucolegnote in Biak Numfor, Papua, Indonesia, are here described. This species is found in mangrove ecosystems and has a similar morphological external character with previously reported which are distributed worldwide from East, South and Southeast Asia to Australia. The IUCN redlist category is discussed in this paper.

KEY WORDS Distribution; Gastropoda; Eastern Indonesia; Leaf-slug; Mangrove ecosystem.

Received 29.10.2019; accepted 21.02.2020; published online 20.03.2020

\section{INTRODUCTION}

The order Sacoglossa inhabits brackish and marine waters worldwide (Jensen, 2007; Yonow, 2008). The Indo-Polynesian region is an area that has a high number of species and distribution of Sacoglossa, but few areas have been extensively sampled (Jensen, 2007). Furthermore, the genus Elysia Risso, 1818 (Plakobranchidae) of the Sacoglossa order in the Indo-Pacific region have 65 species (Jensen, 1992). To the family Plakobranchidae belongs generally small species of heterobranch sea slugs (for- merly known as Opisthobranchia); it is also the largest family of Sacoglossa (Yonow, 2008).

In general, all sacoglossans, including the genus Elysia, are herbivores (Jensen, 1997) with algae as a food source (Jensen, 1993; 1994). They are usually less than $1 \mathrm{~cm}$ in size (Swennen, 2011; Bourke et al., 2016) and only a few species occur in the mangrove ecosystem (Jensen, 1996; Swennen, 2011; Bourke et al., 2016). Their external morphology includes a slender head, dorsal rhinophores, eyes, wing-like parapodia, anus located behind the rhinophores, and oral tentacles are absent (Jensen, 
1992; Jensen, 1996). Many species have symbiotic algal chloroplasts (Jensen, 1997; Wägele \& Johnsen, 2001). Their body coloration varies according to their food sources (Jesus et al., 2010; Costa et al., 2012). Elysia leucolegnote (Jensen, 1990) has been found in the last 2 decades but appears to have a patchy distribution (Swennen, 2011). The genus Elysia has not been reported in Indonesia before, furthermore the aim of this study is to report on the external morphology, distribution, habitat for the first time in Indonesia and IUCN red list categories of E. leucolegnote.

\section{MATERIALS AND METHODS}

The study was conducted in the Biak Barat mangrove ecosystem $\left(1^{\circ} 0{ }^{\prime} 33,715^{\prime \prime} \mathrm{N}\right.$ and $135^{\circ} 48^{\prime}$ 54.83” E), Biak Numfor District, Papua, Indonesia in August 2015 (Fig. 1). The mangrove trees found at the study site were Avicennia sp., Bruguiera sp., Rhizophora sp., and Sonneratia sp. The sampling was conducted with a survey around the mangrove root. The specimens found were 3 individuals, furthermore photographed in situ and image $\mathbf{J}$ was used to measure the external morphology (Figs. 2$5)$. The identification of E. leucolegnote was according to Swennen (2011).

\section{RESULTS AND DISCUSSION}

The specimens of E. leucolegnote had a total length of $0.6 \mathrm{~cm}$ to $1.8 \mathrm{~cm}(\mathrm{n}=3)$, the average length of rhinophores was $0.03 \mathrm{~cm}$, a white triangle in the

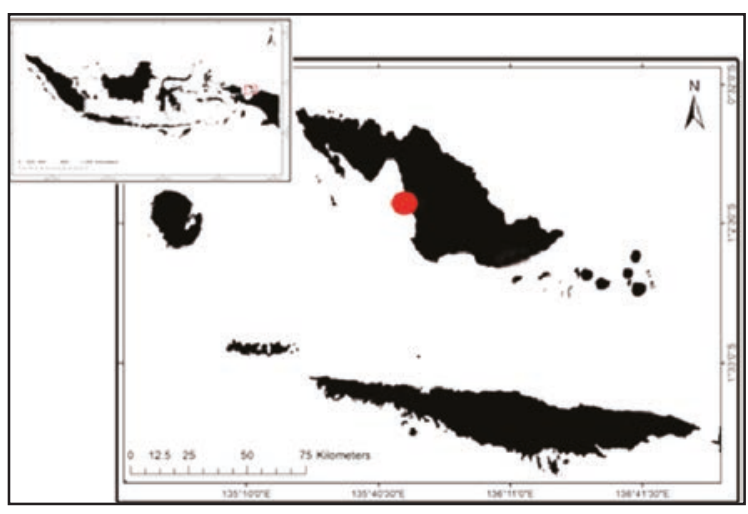

Figure 1. Map showing the study site (red circle). head extending to the rhinophores (Fig. 2), yellowish green on the head and body, white bands along the parapodia both sides and colored spots (Fig. 3) of varying sizes. One specimen of E. leucolegnote was missing one rhinophore and some had damage of the edges of the parapodia (Fig. 4). Specimens of E. leucolegnote were found at depths of 5 to 7 cm (Fig. 5), located among the Rhizophora sp. Roots with 100\% water clearness and mud substrate (Fig. 2). Based on IUCN red categories, species of E. leucolegnote is data deficient.

The specimens of E. leucolegnote found in this study is longer compared to most previous studies in which specimens were more than $1 \mathrm{~cm}$, but had similar characteristics, namely rhinophores and a white triangle on the head, yellowish green color on the head and body, white bands along the parapodia both sides (Jensen, 1990; Swennen, 2011; Sreeraj et al., 2012; Bourke et al., 2016). Mostly of species from the genus Elysia have bands on parapodia and colored spots of varying sizes on the body (Jensen, 1992). Specimens with damage in the parapodia of E. leucolegnote were also found in this study. The damage consisted of smaller or larger parts missing, or some had a hole in parapodia, which may have caused by crab or bird and will heal totally after feeding (Swennen, 2011).

Previous studies showed that E. leucolegnote were found in the mangrove ecosystem (Jensen, 1990; Swennen, 2011; Bourke et al., 2016) with clear waters, under mangrove roots and mud substrate (Swennen, 2011; Bourke et al., 2016). Furthermore, E. leucolegnote can be found at low tide, anaerobic water conditions with white colonies and borders of sulphur bacteria (Swennen, 2011). This species was often found solitary in the mangrove ecosystem substrate. According to Swennen (2011), at the lowest tide, E. leucolegnote will aggregate in small ponds containing water.

Elysia leucolegnote was originally found initially in Hong Kong (Jensen, 1990), then in Thailand and Singapore (Swennen, 2011), Andaman Island, India (Sreeraj et al., 2012), Australia (Bourke et al., 2016), and Indonesia (present study) (Fig. 6). The distribution of E. leucolegnote now includes the tropics of West Pacific and East Indian Ocean, as well as eastern Indonesia and northern Australia. Swennen (2011) predicted that E. leucolegnote would be distributed worldwide from East, South and Southeast Asia to Australia (Fig. 6). 

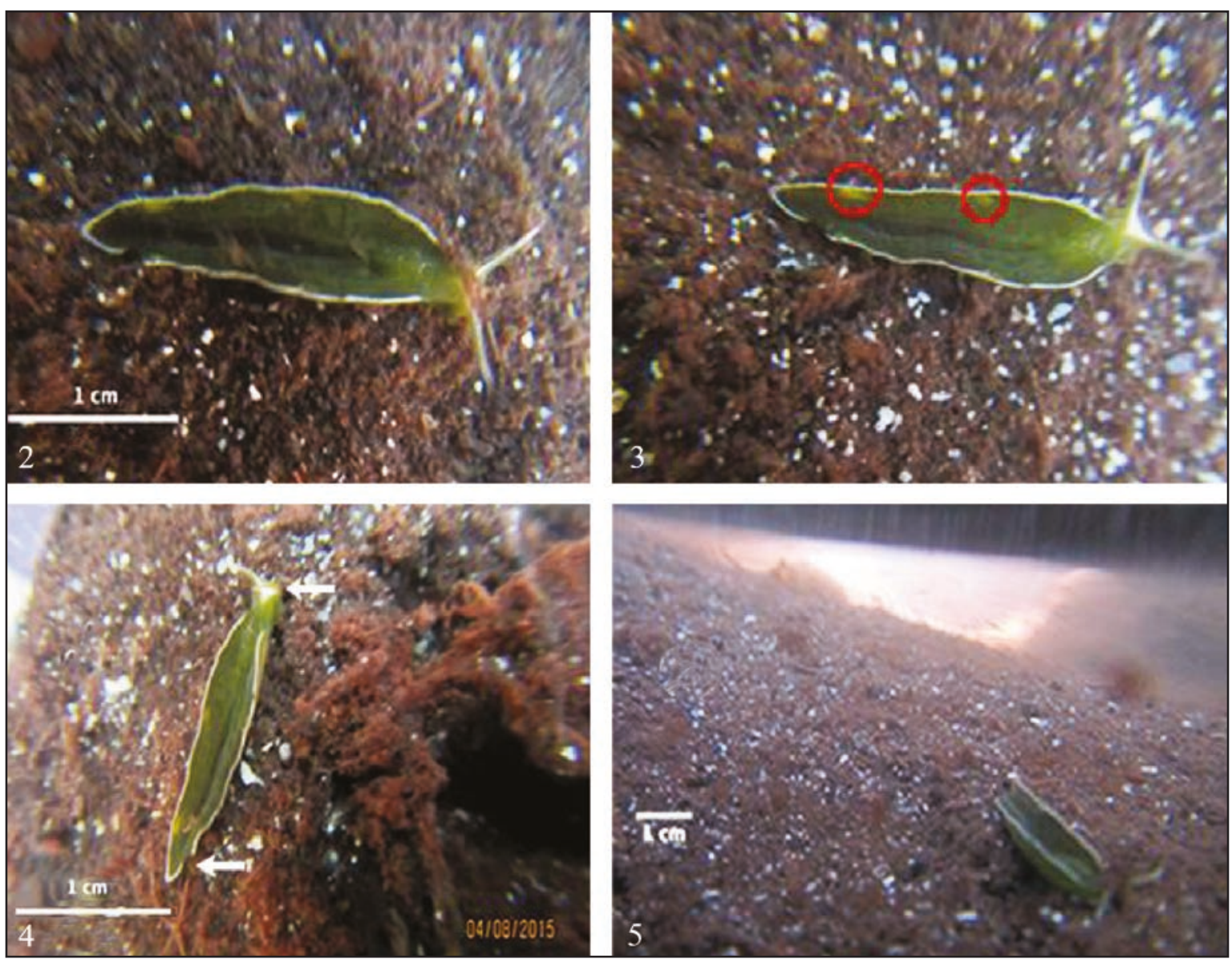

Figures 2-5. External character morphology and habitat of E. leucolegnote found in a mangrove ecosystem of Biak Numfor District, Papua, Indonesia.

The morphology, adaptation and evolution genus of Elysia has been known by previous studies (Jensen, 1990; 1992; 1993; 1994; 1996; 1997) but data on distribution are lacking, as in IUCN red list category this species is data deficient (IUCN, 2012). This category indicates that more information is needed about the distribution and abundance of this species and habitat, especially in Indonesia. Furthermore, the habitat of E. leucolegnote can be commonly found in mangrove ecosystems (Swennen, 2011; Bourke et al., 2016) and Indonesia is a country that has the largest distribution of mangrove ecosystems in the world (Polidoro et al., 2010). Since mangrove ecosystems have declined in decades due to over-exploitation (Polidoro et al., 2010), the impact will directly decline the number of E. leucolegnote in nature. Therefore, in order to prevent the extinc- tion of this species in nature, we need to protect the mangrove ecosystem.

\section{ACKNOWLEDGEMENTS}

The authors would like to thank Nathalie Yonow (Conservation Ecology Research Team, Department of Biosciences, Swansea University, UK), Richard C. Willan (Senior Curator, Molluscs, Museum and Art Gallery of the Northern Territory, Australia), Cornelis (Kees) Swennen (Faculty of Science and Technology, Prince of Songkla University, Thailand), Kathe R. Jensen (Zoological Museum, Danish National Museum of Natural History, Universitetsparken, Copenhagen, Denmark) for constructive discussions in this study. Rifqiah Awaliah and Eryk Andreas are thanked for correcting the English. 


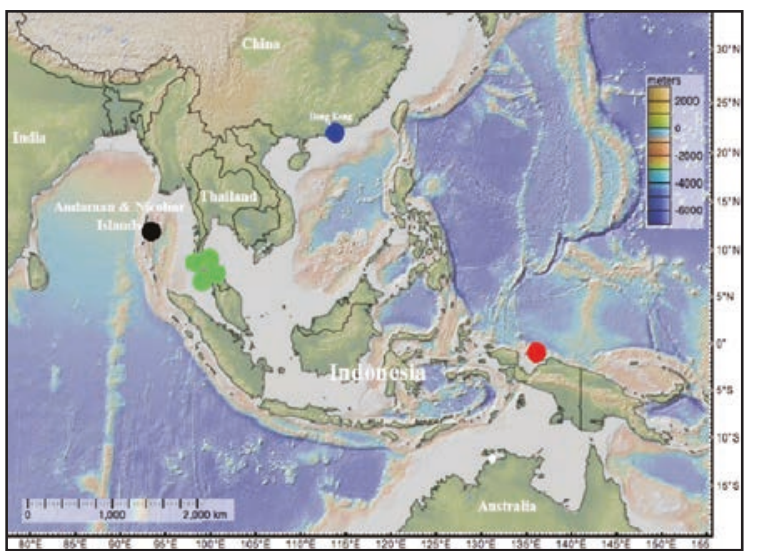

Figure 6. Map showing distribution of Elysia leucolegnote (blue, black, green, and white circles from Jensen (1990), Sreeraj et al. (2012), Swennen (2011), Bourke et al. (2016), respectively, and red for this study).

\section{REFERENCES}

Bourke A.J., Walker C. and Willan R.C., 2016. First record of two mangrove leaf slugs, Elysia leucolegnote and E. bangtawaensis (Sacoglossa: Plakobranchidae), in mangrove forests in the Northern Territory. Northern Territory Naturalist, 27: 97-101.

Costa J., Giménez-Casalduero F., Melo R. \& Jesus B., 2012. Colour morphotypes of Elysia timida (Sacoglossa, Gastropoda) are determined by light acclimation in food algae. Aquatic Biology, 17: 81-89. https://doi.org/10.3354/ab00446

IUCN, 2012. IUCN Red List Categories and Criteria: Version 3.1. Second edition. Gland, Switzerland and Cambridge, UK: IUCN. iv + 32 pp.

Jensen K.R., 1990. Three new species of Ascoglossa (Mollusca, Opisthobranchia) from Hong Kong, and a description of the internal anatomy of Costasiella pallida Jensen, 1985. In: Morton B., The marine flora and fauna of Hong Kong and southern China II. Proceedings of the Second International Marine Biological Workshop: The Marine Flora and Fauna of Hong Kong and Southern China, Hong Kong, 2-24 April 1986. Hong Kong University Press. Hong Kong, 419-432.

Jensen K.R., 1992. Anatomy of some Indo-Pacific Elysiidae (Opisthobranchia: Sacoglossa =Ascoglossa), with a discussion of the generic division and phylogeny. Journal of Molluscan Studies, 58: 257-296.

Jensen K.R., 1993. Morphological adaptations and plasticity of radular teeth of the Sacoglossa (=As- coglossa) (Mollusca: Opisthobranchia) in relation to their food plants. Biological Journal of the Linnean Society, 48: 135-155.

Jensen K.R., 1994. Behavioural adaptations and diet specificity of sacoglossan opisthobranchs. Ethology Ecology and Evolution, 6: 87-101.

Jensen K.R., 1996. Phylogenetic systematics and classification of the Sacoglossa (Mollusca, Gastropoda, Opisthobranchia). Philosophical Transactions of the Royal Society B, 351: 91-122.

Jensen K.R., 1997. Evolution of the Sacoglossa (Mollusca, Opisthobranchia) and the ecological associations with their food plants. Evolutionary Ecology, 11: 301-335.

Jensen K.R., 2007. Biogeography of the Sacoglossa (Mollusca, Opisthobranchia). Bonner zoologische Beiträge, 55: 255-281.

Jesus B., Ventura P. \& Calado G., 2010. Behaviour and a functional xanthophyll cycle enhance photo-regulation mechanisms in the solar-powered sea slug Elysia timida (Risso, 1818). Journal of Experimental Marine Biology and Ecology, 395: 98-105. https:// doi.org/ 10.1016/j.jembe.2010.08.021

Polidoro B.A., Carpenter K.E., Collins L., Duke N.C., Ellison A.M., Ellison J.C., Farnsworth E.J., Fernando E.S., Kathiresan K., Koedam N.E., Livingstone S.R., Miyagi T., Moore G.E., Ngoc Nam V., Ong J.E., Primavera J.H., Salmo III S.G., Sanciangco J.C., Sukardjo S., Wang Y. \& Hong Yong J.W., 2010. The loss of species: Mangrove extinction risk and geographic areas of global concern. PLOS ONE, 5(4): e10095. https://doi.org/10.1371/journal.pone.0010 095

Sreeraj C.R., Sivaperuman C. \& Raghunathan C., 2012. Report on ten newly recorded Opisthobranchs (Opisthobranchia, Gastropoda) from Andaman and Nicobar Islands, India. International Journal of Oceanography and Marine Ecological System, 1: 5059.

Swennen C.K., 2011. Large mangrove-dwelling Elysia species in Asia, with descriptions of two new species (Gastropoda: Opistobranchia: Sacoglossa). The Raffles Bulletin of Zoology, 59: 29-37.

Wägele H. \& Johnsen G., 2001. Observations on the histology and photosynthetic performance of "solarpowered" opisthobranchs (Mollusca, Gastropoda, Opisthobranchia) containing symbiotic chloroplasts or zooxanthellae. Organisms Diversity \& Evolution, 1: 193-210.

Yonow N., 2008. Sea slugs of the red sea. Pensoft Publishers. Bulgaria, 294 pp. 